\title{
Fluid Geochemistry and Volcanic Unrest: Dissolving the Haze in Time and Space
}

\author{
Dmitri Rouwet, Silvana Hidalgo, Erouscilla P. Joseph \\ and Gino González-llama
}

\begin{abstract}
The heat and gas released by a degassing magma affects the overlying predominantly meteoric aquifers to form magmatic-hydrothermal systems inside the solid body of a volcano. This chapter reviews how fluid geochemical signals help to track the evolution throughout the various stages of volcanic unrest. A direct view into a degassing magma is possible at open-conduit degassing volcanoes. Nevertheless, in most cases gas is trapped (i.e. scrubbed) by abundant water, leading to the loss of the pure signal the magma ideally provides. Deciphering how magmatic gas rises through, reacts, and re-equilibrates with the liquids in the magmatic-hydrothermal system in time and space is the only way to trace back to the pure signal. The most indicative magmatic gas species $\left(\mathrm{CO}_{2}, \mathrm{SO}_{2}-\mathrm{H}_{2} \mathrm{~S}, \mathrm{HCl}\right.$ and $\left.\mathrm{HF}\right)$ are released as a function of their solubility in magma. The less soluble gas species are released early from a magma at higher pressure conditions $\left(\mathrm{CO}_{2}\right)$ (deeper), whereas the more soluble species are released later, at lower pressures $\left(\mathrm{SO}_{2}, \mathrm{HCl}\right.$ and $\left.\mathrm{HF}\right)$ (shallower depth). When these gases hit the water during their rise towards the surface, they will be more or less scrubbed. Depending on the chemical equilibria inside the magmatic-hydrothermal system (e.g. $\mathrm{SO}_{2}-$ $\mathrm{H}_{2} \mathrm{~S}$ conversion, acidity), the gas that eventually reaches the surface will carry the history of its rise from bottom to top. Tracking volcanic unrest implies a time frame; the kinetics of magma degassing throughout the liquid cocktail inside the volcano impose the maximum resolution the volcano provides and hence the monitoring time window to be adopted for
\end{abstract}

D. Rouwet $(\bowtie)$

Istituto Nazionale di Geofisica e Vulcanologia,

Sezione di Bologna, Via Donato Creti 12, 40128

Bologna, Italy

e-mail: dmitri.rouwet@ingv.it

S. Hidalgo

Instituto Geofisico, Escuela Politécnica Nacional, Quito, Ecuador
E.P. Joseph

Seismic Research Centre, University of the West Indies, St. Augustine, Trinidad \& Tobago

G. González-Ilama

Centro de Investigaciones en Ciencias Geológicas, Universidad de Costa Rica, San José, Costa Rica 
each volcano. Gas-dominated systems are "faster" and require a higher monitoring frequency, water-dominated systems are slower and require a lower monitoring frequency.

\section{Resumen}

El calor y gas liberados por la desgasificación del magma afecta los acuíferos de origen predominantemente meteórico para formar sistemas magmático-hidrotermales dentro el cuerpo sólido del volcán. Este capítulo revisa como la geoquímica de fluidos puede ayudar a trazar la evolución a través de las varias etapas de "unrest" volcánico. Una visión directa dentro de un magma en desgasificación es solo posible para volcanes de conducto abierto. Sin embargo, en la mayoría de las situaciones el gas queda atrapado (i.e. "scrubbing") en el agua, que conduce a la pérdida de la señal pura que el magma idealmente puede proporcionar. Descifrar como el magma sube a través de los líquidos, y reacciona y re-equilibra con ellos dentro el sistema magmático-hidrotermal, en un marco de tiempo y espacio, es la única manera para rastrear el origen de la señal del magma. La desgasificación de magma se da por cuatro procesos: (1) durante la subida de magma, (2) por la descompresión debido al eliminar una porción del edificio volcánico, (3) debido a la convección interna dentro la cámara magmática, o (4) después de "ebullición secundaria" siguiendo el enfriamiento y consecuente cristalización. Las especies gaseosas magmáticas más indicativas $\left(\mathrm{CO}_{2}, \mathrm{SO}_{2}-\mathrm{H}_{2} \mathrm{~S}, \mathrm{HCl}\right.$ y $\left.\mathrm{HF}\right)$ se liberan en función de su solubilidad en el magma. Las especies menos solubles se liberan antes del magma, bajo regímenes de presiones más altas $\left(\mathrm{CO}_{2}\right)$, mientras que las especies más solubles se liberan después, bajo regímenes de presiones más bajas $\left(\mathrm{SO}_{2}, \mathrm{HCl}\right.$ y $\left.\mathrm{HF}\right)$. En términos espaciales, $\mathrm{CO}_{2}$ se libera a lo largo de una área espacial más amplia (desde lo más profundo). La presencia de $\mathrm{SO}_{2}$ es una indicación clara de un magma que sube hacia un ambiente más somero. La llegada de $\mathrm{HCl}$ en la superficie generalmente indica la presencia de una remesa de magma somera (cientos de metros hasta pocos kilómetros). Especialmente un aumento en la proporción $\mathrm{CO}_{2} / \mathrm{SO}_{2}$ es indicativo para elucidar un estado de "inquietud" ("unrest"). Una disminución consecutiva en el $\mathrm{CO}_{2} / \mathrm{SO}_{2}$, después de un aumento, es una indicación de que el magma está cerca de la superficie y es propenso a una erupción. Cuando estos gases alcanzan el agua durante su ascenso hacia la superficie, serán más, o menos, absorbidos. Dependiendo de los equilibrios químicos dentro el sistema magmático-hidrotermal (e.g. conversión de $\mathrm{SO}_{2}-\mathrm{H}_{2} \mathrm{~S}$, acidez), el gas que al final llega a la superficie lleva consigo la historia de su ascenso desde el fondo hasta la superficie. La desgasificación magmática es un proceso más rápido, mientras que la dinámica hidrotermal en el sistema rocoso $\mathrm{FeO}-\mathrm{FeO}_{1.5}$ es más lenta. Por eso, el $\mathrm{H}_{2} \mathrm{~S}$ se suele llamar un "gas hidrotermal", y el $\mathrm{SO}_{2}$ un "gas magmático". Trazar "unrest volcánico" implica un encuadramiento de tiempo más especifico. Si la ventana de tiempo de monitoreo es más largo 
que el tiempo definido por la cinética de la migración de gas, los detalles de la dinámica de desgasificación se perderán inevitablemente. Contrariamente, si la ventana de tiempo de monitoreo es más corto que la ventana definida por la cinética de la migración de gas, en tal caso, resultará en una visión demasiado detallada de lo que el sistema magmático-hidrotermal puede proveer. Estudios recientes han demostrado que acuíferos extremadamente ácidos pueden "desacelerar" la señal dejada por el sistema magmático-hidrotermal dominado por el gas (e.g. fumarolas), pero pueden "acelerar" la señal dejada por el sistema magmático-hidrotermal dominado por agua (e.g. lagos cratéricos ácidos). Estos hallazgos tienen implicaciones significativas para el encuadramiento de tiempo en reconocer la desgasificación magmática, y por tanto, para la frecuencia del monitoreo.

\section{Keywords}

Fluid geochemistry - Magmatic-hydrothermal systems • Volcanic unrest • Volcano monitoring

\section{Palabras clave}

Geoquímica de fluidos • Sistemas magmático-hidrotermales • Inquietud volcánica $\cdot$ Monitoreo volcánico

\section{Introduction}

Fluid geochemical monitoring tracks variations in gaseous species and fluid phases released in various manners from a volcano. Fluids infiltrate, move, migrate, rise, react and re-equilibrate in the water- and vapor-filled solid body of the volcano. These processes are invisible as they occur in the subsurface, and can only be deduced from measurements at the surface. Nevertheless, gas and water are more mobile than rock and, when a volcano shifts into the gear of unrest, a change in degassing is often the first sign to be detected. As such, fluid geochemistry offers a crucial means to recognize unrest in a timely matter.

Most volcanic edifices store a large volume of water, as cold or thermal aquifers, with various hydrogeological architectures. When gas hits water in its rise towards the surface, the original signature of the gas is mostly lost. This disadvantage can however be overcome.
Understanding how gas absorbs and solutes react in the liquid phase, and how it is eventually released to the atmosphere, is key to linking surface manifestations to magma dynamics.

Volcano monitoring largely focuses on how, where and when magma migrates towards the surface, as, intrinsically, every magmatic eruption is anticipated by magma rise. Nevertheless, volcanoes can become hazardous even without an eruption. A volcano is in a state of magmatic unrest if we recognize signals of a magma-on-the-move; in any other situation, given volcanic unrest, the volcano is in a state of non-magmatic unrest (hydrothermal or tectonic) (Rouwet et al. 2014a). To recognize volcanic unrest, the background behavior of a volcanic system should be tracked for a sufficiently long period, in order to know when a deviation from this background becomes a cause for concern (i.e. unrest, Phillipson et al. 2013). This background behavior and deviations from it are volcano-specific and can be monitored in several 
ways, besides the geochemical approach reviewed here.

The aim of this chapter is to scan through magmatic-hydrothermal systems during the process of magmatic degassing, from bottom to top, and describe how fluids behave in time and space. What are the lessons learned from fluid geochemistry throughout the evolution of volcanic quiescence, re-awakening, volcanic unrest, magmatic unrest and non-magmatic/hydrothermal unrest?

\section{Magmatic-Hydrothermal Manifestations}

One of the first signs of re-awakening after prolonged volcanic quiescence to a state that eventually causes concern is often the appearance of fumarolic exhalations from a crater. This happened, for instance, in 1994 during the reawakening of Popocatépetl (Mexico), and recently, at Cotopaxi (Ecuador), both VUELCO target volcanoes (De la Cruz-Reyna and Tilling 2008; Hall and Mothes 2008) (Fig. 1a). For open-conduit volcanoes the presence of a plume (i.e. a visible gas-vapor cloud originating from an open volcano crater) can become the prominent manifestation of degassing.

Some volcanoes are characterized by decade to century long high-temperature fumarolic degassing in a closed-conduit setting (Fig. 1b), suggesting the presence of a stable, but shallow magma chamber. This constantly hightemperature background degassing is generally no sign of unrest (e.g. Momotombo's $>700{ }^{\circ} \mathrm{C}$, Satsuma-Iwojima's $>900{ }^{\circ} \mathrm{C}$ and Kudryavy's $>700{ }^{\circ} \mathrm{C}$; Menyailov et al. 1986; Shinohara et al. 1993; Taran et al. 1995), whereas the increase of fumarolic temperatures from low (boiling point of water at a given altitude, hence atmospheric pressure) to high (above boiling to magmatic temperature) can be a sign of resumed unrest (e.g. the 1980-1990s crisis at Vulcano, Italy, Capasso et al. 1997).

Magmatic-hydrothermal systems are aquifers inside a volcano or beneath a volcanic area, heated by a magma, at an unspecified depth. The origin of the water is generally meteoric (i.e. rain, snow and its melt water). How hot, and how gas-rich such magmatic-hydrothermal systems are depend on the proportion of the water volume with respect to the heat and gas provided by the magma. The latter depends on the residing depth of the magma. Boilingtemperature fumaroles are a common manifestation at magmatic-hydrothermal systems (Fig. 1c). When the water table of such systems intersects the surface, in craters or volcano flanks, boiling pools appear (Fig. 1d). Such pools can manifest bubbling degassing, and are nothing less than a water-rich fumarole (Fig. 1 e). Depending on the dominant gas they exhale, paired with water vapor, the manifestations are called solfataras (S-rich gases) or mofettes $\left(\mathrm{CO}_{2^{-}}\right.$ rich gases); depending on the temperature and vapor/water proportion they emit they are called fumaroles (boiling or above boiling steam vents), thermal springs (liquid water emission) or geysers (water + vapor jets with a cyclic behavior). Thermal springs can discharge inside active craters or on volcano flanks in a degassed state, without bubbling or boiling (Fig. 1f). Heated water can fill (parts of) craters and form volcanic lakes (Fig. 1g). Depending on the degassing state and depth of the underlying magma, degassing features (bubbling or diffuse degassing) and evaporation can occur at the lake surface (Fig. 1h).

The pictures of the degassing manifestations in Fig. 1 show a trend from gas-dominated, active plume degassing in an open-conduit setting towards more water-dominated, hydrothermal, passive degassing in a closed-conduit setting. These visual observations only give a first glance of magmatic-hydrothermal activity, and do not reflect the state of unrest of a volcano. Throughout the life-time of magmatichydrothermal systems (centuries to millenia) volcanoes can evolve from gas-dominated to water-dominated, and vice versa. The next sections present what we know on the theoretical level, following the laws of chemistry. Despite these classic rules, it will become clear that the range of manifestations and variations in fluid signatures is wide, and volcano-dependent. 

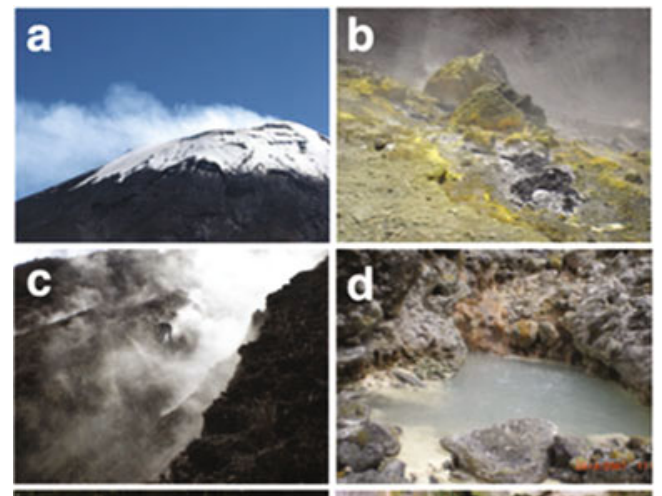

\section{gas-dominant}
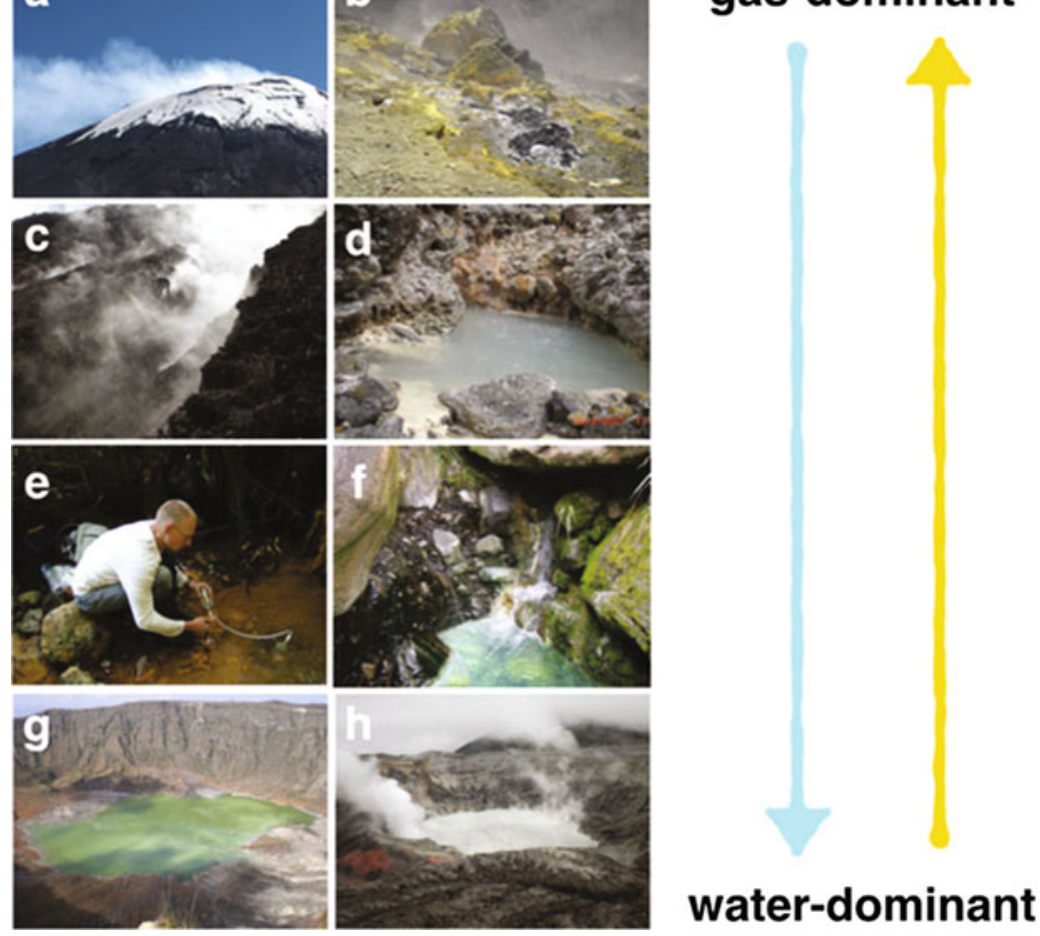

Fig. 1 Degassing manifestations at magmatichydrothermal systems. a Open-conduit degassing at Popocatépetl. b High-temperature fumarolic degassing at Vulcano. c Boiling-temperature fumarolic degassing at the Arbol Quemado fracture in the Turrialba crater area. d Boiling pools inside the El Chichón crater. e Bubbling thermal spring at the SE flank of El Chichón. $\mathbf{f}$ Thermal flank spring at El Chichón. g The El Chichón crater lake. h Evaporative degassing from Laguna Caliente, Poás. The cyan arrow points towards water-dominance; the yellow arrow towards more gas-dominance

\section{Magma Degassing from Bottom to Top}

\section{Magma Degassing}

The degassing of a magma increases when the confining pressure in the magma decreases. Magma decompression can occur in four ways (Fig. 2): (1) magma rise, (2) decompression by uncovering a portion of the volcanic edifice, (3) internal convection in a magma chamber, or (4) secondary boiling upon cooling and consequent crystallization. The first process is often induced by the input of a deeper magma, into a shallower magma chamber. Magma rise towards the lower pressure regime results from the buoyancy difference between the stagnant magma, the rising new melt and the surrounding rocks. The second degassing process can be triggered by the mass removal from part of the volcanic edifice. This superficial process can even trigger eruptions (e.g. 1980 Mt St. Helens). Internal magma convection causes degassing of a less dense, gas-rich magma batch. Once degassed, the now denser magma batch sinks (e.g. Stromboli, Aiuppa et al. 2009). The fourth process increases the gas/melt ratio in the magma, due to the loss of crystals from the cooling magma, hence favoring degassing.

Based on gas geochemistry only it is hard to rule out which process actually occurs at depth, and thus distinguish between magmatic and non-magmatic unrest. Geophysical signals are needed. Following the definition of magmatic unrest by Rouwet et al. (2014a) (i.e. the 
recognition of a magma-on-the-move), only the first process is initially consistent with the requisite of magmatic unrest.

Variations in magma degassing can be detected both qualitatively and quantitatively. Detailed insights in the degassing state of a magma can only be obtained if both are measured contemporaneously. Which gas species are released, how much and when? When a magma starts to degas, by any of the above processes, the less soluble species is released first (i.e. at higher confining pressure in the magma chamber). The order in solubility of indicative magmatic gas species is $\mathrm{CO}_{2}<\mathrm{SO}_{2}<\mathrm{HCl}<\mathrm{HF}$; the order of release when a magma progressively degasses is "CO 2 -first till HF-last" (Giggenbach 1987). Hence, tracking variations in ratios between these species gives qualitative insights into the degassing state of a magma. A consecutive increase with time in first $\mathrm{CO}_{2} / \mathrm{SO}_{2}$, then $\mathrm{SO}_{2} /$ $\mathrm{HCl}$, then $\mathrm{HCl} / \mathrm{HF}$ ratios reflects the evolution in degassing state from a magma moving from depth towards the surface. Especially an increase in the $\mathrm{CO}_{2} / \mathrm{SO}_{2}$ is indicative of the state of unrest, pointing to an input of poorly degassed magma at great depths. A consecutive decrease in $\mathrm{CO}_{2} / \mathrm{SO}_{2}$ ratio, after the increase, is an indication of magma moving towards the surface. The latter two ratios come into play when eruption of magma is imminent, or even ongoing: the highly soluble species $\mathrm{HCl}$ and $\mathrm{HF}$ are released from a highly degassed magma, a situation that reflects near-surface degassing (Aiuppa et al. 2002). The arrival of $\mathrm{HCl}$ at the surface (e.g. in

Fig. 2 Sketch of the four mechanisms that instigate magma degassing (not to scale)

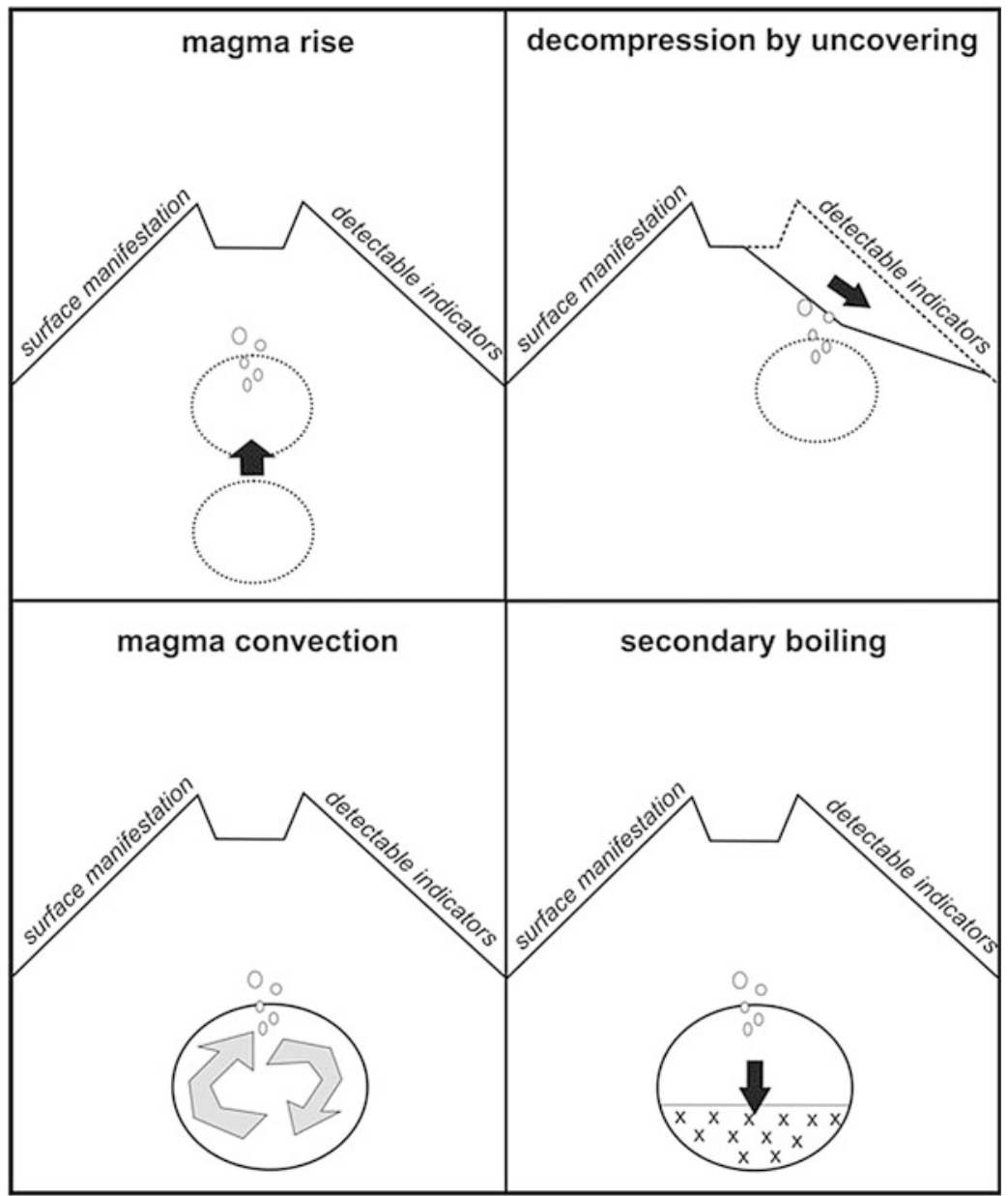


fumaroles) generally indicates the presence of a shallow magma batch (hundreds of meters, or less).

The "purest" proxy of the magmatic gas is provided by direct sampling of a fumarole with a near-magmatic temperature, followed by the analysis of its chemical composition. During the past five-six decades fumarolic gases have been extensively sampled and analyzed representing a wide range of temperatures and states of volcanic activity. Table 1 presents a compilation of chemical compositions of fumarolic gases for the high- and low-temperature ranges.

Before dealing with the abundant water vapor in fumaroles, we tackle the other gas species in the "dry-gas phase". Regardless of the fumarole temperature, $\mathrm{CO}_{2}$ is the most abundant gas species (Table 1). $\mathrm{CO}_{2}$ is often released at the surface across a wider spatial extent, as it degasses from greater depth (Fig. 3). Old and deep magma bodies can continue to release $\mathrm{CO}_{2}$ for tens to hundreds of millenia.

The second most abundant "dry-gas" species are the sulphur species $\mathrm{SO}_{2}$ and $\mathrm{H}_{2} \mathrm{~S}$. $\mathrm{SO}_{2}$ is more soluble in magma than $\mathrm{CO}_{2}$, and will thus be released at lower pressure. As $\mathrm{SO}_{2}$ degasses at lower depth, the degassing tends to be more centralized along the central conduit (open or closed) of the volcano (Fig. 3). As such, $\mathrm{SO}_{2}$ is often measured in volcanic plumes. An increase of $\mathrm{SO}_{2}$ has often been interpreted as an indicator of magma rise into the shallower environment.
At high-temperature magmatic conditions the following reaction applies (Giggenbach 1987; Delmelle and Bernard 2015):

$$
3 \mathrm{SO}_{2}+7 \mathrm{H}_{2}=\mathrm{H}_{2} \mathrm{~S}+2 \mathrm{~S}^{\circ}+6 \mathrm{H}_{2} \mathrm{O}
$$

This explains the presence of both $\mathrm{SO}_{2}$ and $\mathrm{H}_{2} \mathrm{~S}$ in high-temperature fumaroles. The $\mathrm{SO}_{2} /$ $\mathrm{H}_{2} \mathrm{~S}$ ratio is sensitive to temperature and the oxidation state (i.e. the role of $\mathrm{H}_{2}$ in Eq. 1 reflects the oxidation vs reduction state, Giggenbach 1987).

On the other hand, it is noted that the low-temperature fumaroles lack $\mathrm{SO}_{2}$, instead, the dominant sulphur species is $\mathrm{H}_{2} \mathrm{~S}$ (Table 1). Low-temperature hydrothermal conditions $\left(\mathrm{T}<300{ }^{\circ} \mathrm{C}\right.$ ) favor the reduced $\mathrm{S}$-species $\mathrm{H}_{2} \mathrm{~S}$ (Table 1), equilibrated by the rock phase, following the reaction:

$$
\mathrm{SO}_{2}+6(\mathrm{FeO})_{\text {rock }}+\mathrm{H}_{2} \mathrm{O}=\mathrm{H}_{2} \mathrm{~S}+6\left(\mathrm{FeO}_{1.5}\right)_{\text {rock }}
$$

or simply through reduction of $\mathrm{SO}_{2}$ in the gaseous environment:

$$
\mathrm{SO}_{2}+\mathrm{H}_{2}=\mathrm{H}_{2} \mathrm{~S}+\mathrm{O}_{2}
$$

To convert $\mathrm{SO}_{2}$ into $\mathrm{H}_{2} \mathrm{~S}$ in a rock matrix ( $\mathrm{FeO}-\mathrm{FeO}_{1.5}$-system), following reaction (2), a major constraint is "sufficient time". Magmatic degassing (Eq. 1) is a faster process, while hydrothermal dynamics (Eq. 2) are slower. This

Table 1 Chemical composition of fumarolic gases (concentrations in micromol/mol), for high (magmatic, 280 $1130{ }^{\circ} \mathrm{C}$ ) and low (hydrothermal, $83^{\circ}-160^{\circ} \mathrm{C}$ ) temperature conditions, expressed as the minimum and maximum measured concentrations for 12 and 59 samples, respectively

\begin{tabular}{l|r|l|l|r|r|r|r|r|r|r|r}
\hline & $\begin{array}{l}\mathrm{T}\left(^{\circ}\right. \\
\mathrm{C})\end{array}$ & $\mathrm{H}_{2} \mathrm{O}$ & $\mathrm{CO}_{2}$ & $\mathrm{SO}_{2}$ & $\mathrm{H}_{2} \mathrm{~S}$ & $\mathrm{HCl}$ & $\mathrm{HF}$ & $\mathrm{H}_{2}$ & $\mathrm{~N}_{2}$ & $\mathrm{CH}_{4}$ & $\mathrm{CO}$ \\
\hline $\begin{array}{l}\text { High-T } \\
\text { minimum (\#12) }\end{array}$ & 280 & 311000 & 1200 & 320 & 4 & 275 & 21 & 3 & 40 & 0.1 & 0.2 \\
\hline $\begin{array}{l}\text { High-T } \\
\text { maximum } \\
(\# 12)\end{array}$ & 1130 & 993000 & 672000 & 67800 & 21460 & 14200 & 2500 & 14900 & 1800 & 7.1 & 4600 \\
\hline $\begin{array}{l}\text { Low-T } \\
\text { minimum (\#59) }\end{array}$ & 83 & 638200 & 2655 & 0 & 0 & 0 & 0 & 16 & 32 & 0.4 & 0.011 \\
\hline $\begin{array}{l}\text { Low-T } \\
\text { maximum } \\
(\# 59)\end{array}$ & 160 & 997200 & 355000 & 0 & 3700 & 0 & 0 & 1220 & 6800 & 5330 & 1.6 \\
\hline
\end{tabular}




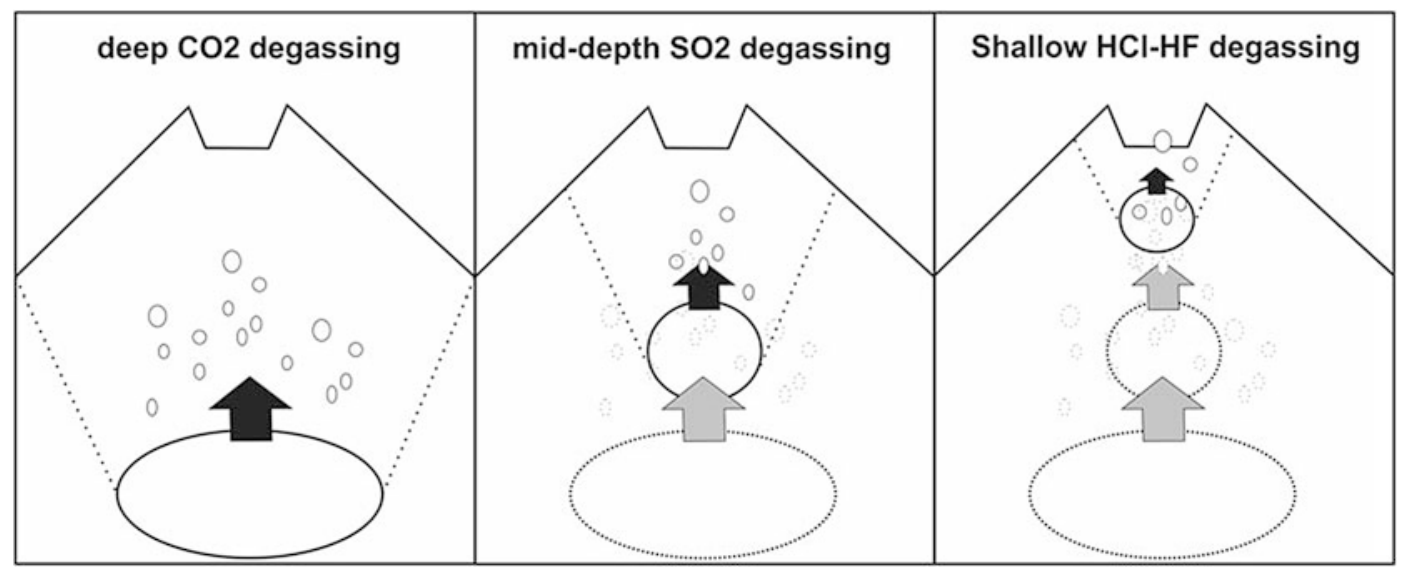

Fig. 3 Sketch of the passing "gas train" during magma degassing, resulting from the difference in solubility of the various gas species (not to scale)

is why $\mathrm{H}_{2} \mathrm{~S}$ is often called a "hydrothermal gas" and $\mathrm{SO}_{2}$ a "magmatic gas" (Table 1).

As noted in Table 1, the major gas species in fumaroles is often water, regardless of their temperature. Even high-temperature fumaroles are water-dominated.

Knowing that water boils at $100{ }^{\circ} \mathrm{C}$ (at atmospheric pressure, at sea level), in theory, the temperature of a fumarole is buffered at $100{ }^{\circ} \mathrm{C}$ and cannot rise until water is exhausted in the underlying plumbing system. Moreover, the critical temperature of water is $374{ }^{\circ} \mathrm{C}$ (i.e. the temperature at which vapor and liquid water cannot coexist anymore), imposing a second temperature buffer. This implies that (1) water directly originates from a high-temperature magma under super-critical conditions ("andesitic water" with $\mathrm{T}>374{ }^{\circ} \mathrm{C}$, Taran et al. 1989), and/or (2) water is excessively present in the fumarole plumbing system with respect to the gas, and will hardly ever exhaust.

\section{When the Gas Hits the Water}

The shallow subsurface environment of the different sections of the Earth's crust hosts numerous aquifers at various depths originating from the infiltration and storage of meteoric water, or seawater in the case of low-lying islands; volcanic edifices are no different, being "small dots" at the Earth's surface. As described before, a magma degasses and heats the space between the magma and the surface, and will inevitably heat and modify the volcanic aquifers. As the magma heats the overlying aquifers, between the magma and the surface, from bottom to top, a gas-only, vapor + gas zone, a vapor + liquid zone and a liquid-only zone can be found (Fig. 4). When a magma rises, or the heat input from the magma increases, the vapor + liquid zone or vapor + gas zone will be pushed upwards until intersecting the surface (e.g. in a volcano crater), manifested at the surface as boiling or bubbling pools and fumaroles (Fig. 4). If the distance between the magma and surface is larger, the thermal aquifer will intersect the surface and create thermal springs (Fig. 4). Facing unrest, a liquid to vapor transition at a surface manifestation reflects heating of the hydrothermal system.

When the above "gas train" (Fig. 3) consecutively reaches the liquid-only zone, gas species will be absorbed and react depending on their specific chemical properties in water. The capacity to absorb magmatic gases in the liquid phase is called "scrubbing" (Symonds et al. 2001). The $\mathrm{CO}_{2}$ that reaches the water from greater depths during magma degassing (Fig. 3), will create $\mathrm{CO}_{2}$-dominated bubbling thermal springs, and $\mathrm{HCO}_{3}$-rich slightly acidic springs (pH 5-7) (Fig. 4). The second least soluble gas species that hits the water is $\mathrm{SO}_{2}$ that will be 


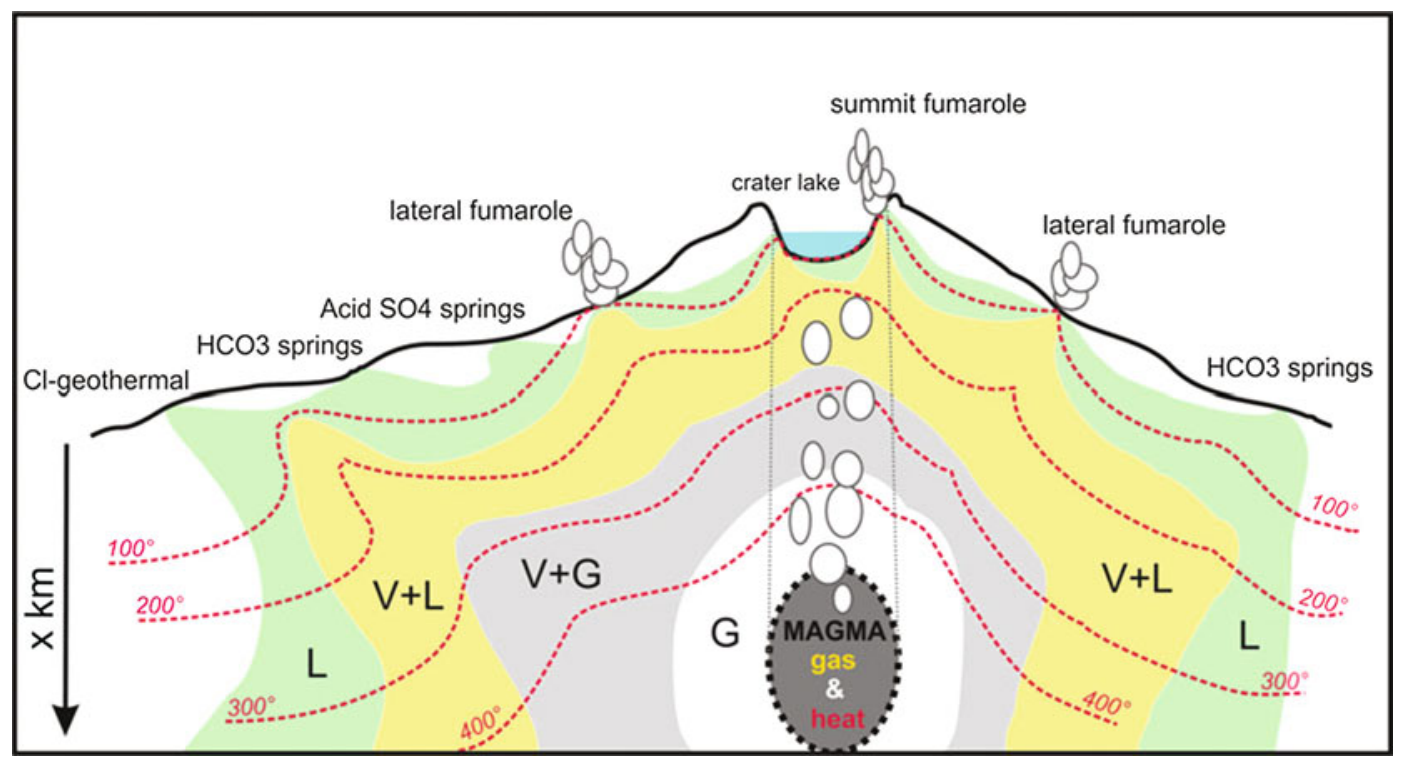

Fig. 4 Sketch of the gas that hits the water in an hypothetical "wet volcano" (not to scale). L = liquid only zone (turquoise area), $\mathrm{V}+\mathrm{L}=$ vapor + liquid zone, (yellow area) $\mathrm{V}+\mathrm{G}=$ vapor + gas zone (grey area), $\mathrm{G}=$ gas only zone (white area around the degassing

hydrolyzed as sulphuric acid $\left(\mathrm{H}_{2} \mathrm{SO}_{4}\right)$ and dissociate into $\mathrm{HSO}_{4}{ }^{-}$or $\mathrm{SO}_{4}{ }^{2-}$, depending on the $\mathrm{pH}$ of the water. The dissolved $\mathrm{H}^{+}$creates the high acidity or low $\mathrm{pH}$, following $\mathrm{pH}=-\log$ $\left[\mathrm{H}^{+}\right]$. Volcanic environments are renowned for being acidic; the acid is generated by the scrubbing of acidic gases into the water.

The following $\mathrm{SO}_{2}$ disproportionation reactions occur (Kusakabe et al. 2000):

$$
3 \mathrm{SO}_{2}+3 \mathrm{H}_{2} \mathrm{O}=2 \mathrm{HSO}_{4^{-}}+\mathrm{S}^{\circ}+2 \mathrm{H}^{+}
$$

or

$$
4 \mathrm{SO}_{2}+4 \mathrm{H}_{2} \mathrm{O}=3 \mathrm{HSO}_{4^{-}}+\mathrm{H}_{2} \mathrm{~S}+3 \mathrm{H}^{+}
$$

Reaction (4) occurs under relatively oxidizing conditions, low temperature and high total sulphur concentrations, whereas reaction (5) occurs under relatively reducing (i.e. oxygen poor) conditions, high temperature and low total sulphur concentrations. "To disproportionate $\mathrm{SO}_{2}$ " means that for each three or four moles of $\mathrm{SO}_{2}$ that hit the water, one mole of $\mathrm{S}^{\circ}$, or one mole of magma, dark grey). Red dotted lines are isotherms. Cl-geothermal water are deep remnant waters, not of interest for geochemical monitoring of volcanoes for being "old and slow"

$\mathrm{H}_{2} \mathrm{~S}$ is given in return (reaction 4 and 5, respectively).

As $\mathrm{SO}_{2}$ degasses at shallower depth in a magma system than $\mathrm{CO}_{2}$, the resulting acid $\mathrm{SO}_{4}$ rich springs are found near the central degassing conduit (e.g. inside active craters). For $\mathrm{SO}_{2^{-}}$ dominated magmatic systems a $\mathrm{pH}$ near 2 or less is common; for $\mathrm{H}_{2} \mathrm{~S}$-dominated hydrothermal systems a $\mathrm{pH}$ of $2-2.5$ is the most acidic water can get (i.e. hydrothermal or "steam heated" waters).

The next gas species to be added to the "liquid cocktail" are $\mathrm{HCl}$ and $\mathrm{HF}$ (Fig. 3). $\mathrm{HCl}$ is highly volatile, but also highly hydrophile. This contradictio in terminis means that when $\mathrm{HCl}_{\mathrm{gas}}$ reaches water it will be trapped in the liquid phase as $\mathrm{Cl}^{-}$and $\mathrm{H}^{+}$. Generally, $\mathrm{Cl}^{-}$is considered "conservative" in the liquid phase, and is therefore often used as a tracer in the hydrothermal environment (see Section "Rock Leaching Upon Weathering"). Conservative means that $\mathrm{Cl}^{-}$can be hardly lost from the solution as $\mathrm{Cl}$-salts are highly soluble in acidic 
and hot environments, and $\mathrm{HCl}$ should not degas from "high $\mathrm{pH}$ water" $(>2)$. Sulphate minerals in their turn can be lost from solutions by precipitation, demonstrating their non-conservative character (Rouwet and Ohba 2015). For extremely acidic environments $(\mathrm{pH} 0$ or $<0)$ the reaction

$$
\mathrm{HCl}=\mathrm{H}^{+}+\mathrm{Cl}^{-}
$$

moves to the left due to an $\mathrm{H}^{+}$excess with respect to $\mathrm{Cl}^{-}$(i.e. $\mathrm{HCl}$ degassing). The same counts for HF. Bearing in mind the abundance of the acid $\mathrm{SO}_{2}$ in the magmatic-hydrothermal environment, providing a large part of the acidity, this "secondary $\mathrm{HCl}$ degassing from the liquid phase" is less unexpected than previously thought. This implies that $\mathrm{HCl}$ can degas from a low-temperature aquifer, as long as the aquifer is extremely acid (Capaccioni et al. 2016). Moreover, as hot water releases vapor, this loss enriches the remnant liquid in solutes, including $\mathrm{H}^{+}$ (i.e. salinity and acidity increase), leading to the fact that even $\mathrm{SO}_{2}$ tends to degas from the liquid, instead of remaining in the water phase as $\mathrm{SO}_{4}{ }^{2-}$ or $\mathrm{HSO}_{4}{ }^{-}$.

Acid water $(\mathrm{pH}<3.8)$ is completely transparent for the omni-present $\mathrm{CO}_{2}$. This implies that $\mathrm{CO}_{2}$, one of the "deepest signals" available for a degassing volcano, will completely outgas from bottom to top. In active craters, often underlain by acidic thermal aquifers, the release of $\mathrm{CO}_{2}$ thus behaves as though there is no water present. This is a great advantage to monitoring volcanoes and tracking unrest, especially to detect the onset of unrest.

In conclusion, the above insights demythologize two generally accepted facts: (1) hightemperature fumaroles cannot contain water vapor (Table 1), and (2) low-temperature fumaroles cannot release acidic gases.

Within the scope of this book, tracking unrest using fluid geochemistry requires the introduction of a time frame, or a monitoring time window and frequency. Does the fumarole reflect the exact moment of degassing, or is it rather an average degassing for the longer previous period stored and steadily released from the magmatic-hydrothermal plumbing system? What is the time delay between the moment the gas hits the water and the eventual release at the surface? The kinetics (i.e. "speed") of the gas migration from a magma towards the surface are still poorly constrained. If we can estimate the residence time of gas and water in the magmatic-hydrothermal system, we are able to define a monitoring time window, and hence adopt an adequate monitoring frequency. As explained, the acidity of the feeding aquifer plays a role. For extreme acidic conditions, less gas scrubbing occurs and the fumarolic system will react faster, and hence, shorter monitoring time windows can be adopted. If the monitoring time window is longer than the window defined by the kinetics of gas migration, details in degassing dynamics will be lost. On the contrary, the monitoring time window should not be a lot shorter than the time window defined by the kinetics of gas migration, if so, it will provide a too detailed view of what the magmatic-hydrothermal system can maximally provide.

\section{The Other Liquid: Elemental Sulphur}

Whereas water melts at $0{ }^{\circ} \mathrm{C}$ and boils at $100{ }^{\circ} \mathrm{C}$, sulphur melts at $119^{\circ} \mathrm{C}$ and boils at $444{ }^{\circ} \mathrm{C}$ (Oppenheimer and Stevenson 1989, and references therein). This physical fact on phase transitions implies that in the hydrothermal environment (boiling water) elemental sulphur is solid, and that during the initial phase of transition towards a more magmatic, high-temperature regime sulphur will become liquid. Molten sulphur in the hydrothermal plumbing system can be remobilized, clear vugs and vents and eventually be expelled as a liquid sulphur flow from fumarole mouths, or "fill-and-freeze" pores in the shallower hydrothermal system. The first process opens up degassing pathways; the second process can decrease rock porosity and permeability near the surface, thus sealing a hydrothermal system. During the evolution from lowtemperature $\left(>119^{\circ} \mathrm{C}\right.$, unrest) towards hightemperature (occasionally magmatic unrest), the viscosity of the liquid sulphur increases 
2000 -fold $\left(>160{ }^{\circ} \mathrm{C}\right)$ to become an extremely efficient sealer of a magmatic-hydrothermal system. Pressure build-up beneath seals in hydrothermal systems can lead to phreatic eruptions (Rouwet and Morrissey 2015; Rouwet et al. 2016). Monitoring fumarolic temperatures is thus essential, and probably one the simplest methods to apply.

\section{Tracking Hydrothermal Unrest and Related Hazards: Methods from Case-Studies}

\section{From Quiescence to Unrest, to Phreatic Eruptions, to Magmatic Eruptions}

\section{Turrialba, Costa Rica (2001-2016)}

A transition from the stable, passively degassing hydrothermal system of Turrialba volcano (Costa Rica), to hydrothermal unrest, to phreatic eruptions, to magmatic eruptions, is a recent example of an evolution from volcanic quiescence heading towards eruption.

In 2001, increased fumarolic activity (appearance of $\mathrm{SO}_{2}$ in late 2001) was paired to seismic swarms and ground deformation (Martini et al. 2010; Vaselli et al. 2009) (i.e. unrest). In 2007, the increased $\mathrm{SO}_{2} / \mathrm{H}_{2} \mathrm{~S}$ molar ratio in fumaroles $(>100)$, combined with an increase in exhalation temperature up to $282{ }^{\circ} \mathrm{C}$ (in early 2008, Martini et al. 2010; Vaselli et al. 2009), point to more oxidized and magmatic conditions (i.e. magmatic unrest). Clear plume degassing resumed in early 2007 (Fig. 5a), and $\mathrm{SO}_{2}$ fluxes reached $740 \mathrm{t} / \mathrm{d}$ in January 2008 (Martini et al. 2010). In late 2009, fumarolic degassing was vigorous and extended into the Arbol Quemado fracture, newly formed in 2002. The first phreatic eruption occurred on 5 January 2010, in the inner crater wall of the actively degassing SW crater. Strong jet-like degassing occurred afterwards from this new vent (Fig. 5b), while diffuse fumarolic degassing diminished in the SW crater. A second phreatic eruption occurred on 12 January 2012, from a vent inside the Arbol Quemado fracture. The day before, this eruption was preceded by liquid sulphur flowing out of the
Arbol Quemado fumaroles (González et al. 2015). A third phreatic eruption episode involved the 2010 and 2012 vents simultaneously (21 May 2013). During this 3.5-year long phreatic cycle the $\mathrm{SO}_{2}$ flux from Turrialba's plume was high: from 2500 to 4300 t/d (Campion et al. 2012; Moussallam et al. 2014). $\mathrm{CO}_{2} / \mathrm{SO}_{2}$ molar ratios in March 2013 were relatively low (2.6), hinting at a $\mathrm{CO}_{2}$-depleted and $\mathrm{SO}_{2}$-rich magma (Moussallam et al. 2014). From 2001 to 2013, Moussallam et al. (2014) suggest the progressive "drying-out" of the underlying hydrothermal system.

The first magmatic eruption at Turrialba since the 1864-1866 phreatomagmatic activity occurred during the night of 29 and 30 October 2014 (Mora-Amador et al. 2015). At the time of writing, the last magmatic eruptions took place in September 2016.

Despite the well-monitored and tracked evolution from volcanic quiescence to magmatic eruption it remains unclear why some volcanoes quickly evolve from quiescence to eruption, while at Turrialba it took 14 years from quiescence to magmatic eruption, passing the complete range of unrest manifestations during this relatively long time span.

\section{Cotopaxi, Ecuador (2015-2016)}

Another example of volcanic quiescence to magmatic unrest is the one of Cotopaxi volcano in 2015. As Cotopaxi is a dangerous volcano whose activity would potentially affect densely populated areas its monitoring network has been continuously improved since the late 70 s. After 73 years of quiescence, the first sign of unrest at Cotopaxi was a progressive increase in the amplitude of transient seismic events in April 2015. $\mathrm{SO}_{2}$ is measured at Cotopaxi by DOAS stations installed on the flanks of the volcano since 2008. The permanently measured $\mathrm{SO}_{2}$ emissions showed an increase on May 20 from almost non detectable up to $\sim 3000 \mathrm{t} / \mathrm{d}$. The fumaroles showed increased activity and a gas plume from the crater was usually observed on clear days. By early June $\mathrm{SO}_{2}$ emissions yielded up to $5000 \mathrm{t} / \mathrm{d}$. On July 20 a green lake was observed filling the crater of the volcano, 

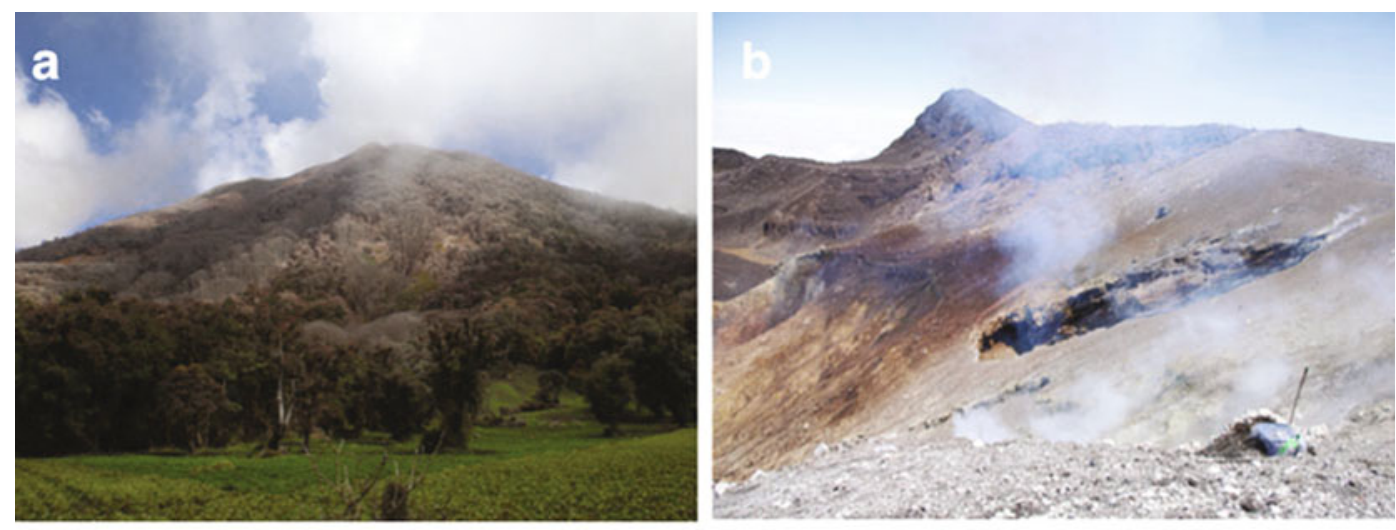

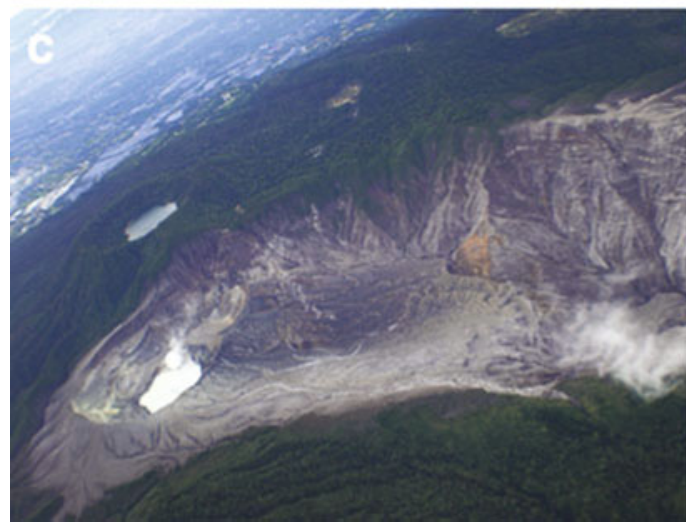

Fig. 5 Hydrothermal unrest at Turrialba, Poás and Irazú volcanoes. a Vegetation die-back due to resumed plume degassing. b The 2010 phreatic eruption vent (picture by S. Calabrese). c Lack of vegetation at Cerro Pelón (Poás)

nevertheless no significant changes in the $\mathrm{SO}_{2}$ emission was observed, suggesting that the lake was of high acidity and/or too small to be an efficient scrubber. The first phreato-magmatic explosions occurred on August 14 and produced ash and gas columns reaching up to $9 \mathrm{~km}$ above the crater. The satellite-borne instruments such as OMI and OMPS reported 16,400 and 12,500 t/d of $\mathrm{SO}_{2}$ released to the atmosphere on that day (http://so2.gsfc.nasa.gov/pix/daily/0815/ecuador_ 0815z.html). Continuous ash emissions followed the initial explosions producing a permanent gas and ash plume drifting westward. $\mathrm{SO}_{2}$ measured in this permanent plume, by mobile-DOAS traverses or by the permanent stations, reached

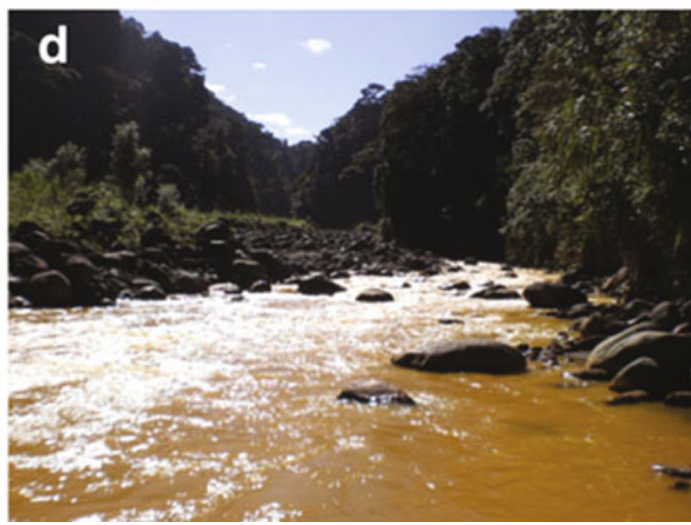

due to plume degassing and acid rain fall downwind. d Efficient rock mass removal through Río Sucio, $30 \mathrm{~km}$ downstream Irazú volcano

$24,000 \mathrm{t} / \mathrm{d}$ and decreased progressively until the end of the activity in late November 2015.

Since June and more consistently since 14 August 2015, BrO was also detected in the plume (Dinger et al. 2016). Airborne Multi-GAS measurements showed that the plume had a low $\mathrm{CO}_{2} /$ $\mathrm{SO}_{2}$ ratio, and that $\mathrm{SO}_{2}$ was $>99 \%$ of total sulfur $\left(\mathrm{SO}_{2}+\mathrm{H}_{2} \mathrm{~S}\right)$, indicating a shallow magmatic origin for the gas. At the time of writing (September 2016), $\mathrm{SO}_{2}$ emissions decreased to background levels. $\mathrm{SO}_{2}$ permanent monitoring proved to be a useful tool at Cotopaxi providing real time data contributing, together with other geophysical methods, to better evaluate volcanic unrest scenarios. 


\section{Gas Impact and Acid Rain}

Persistent high-temperature fumarolic and plume degassing impact volcano flanks down-wind (Fig. 5c). This can happen when it rains through a plume, generating acid rain. Many volcanoes are subject to such long-term, non-eruptive hazard, making the surrounding ground harsh living environments. Other volcanoes suffer vegetation die-back, when activity resumes after prolonged quiescence (Fig. 5a). This was clearly visible during the increased activity at Turrialba volcano (Section "Turrialba, Costa Rica (2001-2016)”, Fig. 5a, b; González et al. 2015) and downwind Poás' western flank (Cerro Pelón, Fig. 5c). To assess such hazards, a meteorological station (wind direction, speed, air humidity and rainfall), and a DOAS device to measure $\mathrm{SO}_{2}$ fluxes are valuable tools.

\section{Rock Leaching upon Weathering}

Absorption of magmatic gases into aquifers creates acidic magmatic-hydrothermal systems that, sooner or later, will exit the volcano. Acidic water attacks the wall rock and becomes loaded with solutes (Delmelle et al. 2015). If (1) meteoric recharge is high, (2) acid input is high, (3) wall rock is fresh, and (4) (thermal) spring water discharge is high, rock leaching capacity can reach thresholds to even mechanically destabilize volcano flanks. Enhanced chemical leaching for long periods favors physical rock removal, causing rock fall, landslides, or even flank and sector collapses of volcanic edifices. Even if magmatic degassing seems absent and a volcano may be long dormant, hazards loom due to the scrubbing capacity of deeper aquifers (Delmelle et al. 2015, and references therein).

The best suited method to quantify and track rock mass removal from a volcanic edifice is by monitoring the discharge rates from thermal springs, and their dissolved solutes and solids. The "Cl-inventory" uses $\mathrm{Cl}$ as the conservative tracer. As mentioned earlier, this is true for less acidic magmatic-hydrothermal systems (Ingebritsen et al. 2001; Taran and Peiffer 2009; Chiodini et al. 2014; Collard et al. 2014). Measuring the Cl-release from rivers draining thermal springs, and knowing the $\mathrm{Cl}$-content and $\mathrm{Cl} /$ solute ratios in thermal spring waters, the rock mass removal rate can be estimated by:

$$
\mathrm{Q}_{\mathrm{r}} * \mathrm{C}_{\mathrm{r}}=\mathrm{Q}_{\mathrm{s}} * \mathrm{C}_{\mathrm{s}}
$$

where $\mathrm{Q}_{\mathrm{r}}$ and $\mathrm{Q}_{\mathrm{s}}$ are the discharges of rivers and thermal springs, respectively, in $\mathrm{L} / \mathrm{s} ; \mathrm{C}_{\mathrm{r}}$ and $\mathrm{C}_{\mathrm{s}}$ are the concentrations of $\mathrm{Cl}$ of rivers and thermal springs, respectively, in $\mathrm{mg} / \mathrm{L}$. Measuring the river discharge $\left(\mathrm{Q}_{\mathrm{r}}\right)$ and analyzing the river and spring waters for its $\mathrm{Cl}$ content $\left(\mathrm{C}_{\mathrm{r}}\right.$ and $\mathrm{C}_{\mathrm{s}}$, respectively) thus enables to estimate the spring discharge $\left(Q_{s}\right)$, which would otherwise be impossible to directly measure in the field (e.g. numerous spring discharges, too irregular spring mouths). This method combines gas-water-rock interaction and hydrology of magmatic-hydrothermal systems in order to assess indirect hazard. Volcanoes with high rock mass removal rates are e.g. Irazú (Costa Rica, Fig. 5d); extremely acidic magmatichydrothermal rock removers are Kawah Ijen (Java), Poás (Costa Rica), and Copahue (Argentina-Chile). In the most extreme cases, the acidity and toxic metal load affects agricultural activities and human health.

Moreover, through the same Cl-inventory approach, the geothermal potential (i.e. heat output) from springs can be estimated, by multiplying the enthalpy of discharged spring waters, often based on geothermometric temperatures of the deep system, with the spring discharge rates. Such estimates were obtained for the active magmatic-hydrothermal systems of El Chichón and Tacaná (both in Chiapas, Mexico; Taran and Peiffer 2009; Collard et al. 2014), and Domuyo (Argentina; Chiodini et al. 2014), and originally of the Cascades Volcanic Range by Ingebritsen et al. (2001). Understanding the state of unrest on the long term of a specific volcano is needed to rule out if the volcano would be a feasible target for geothermal exploitation, or not. 


\section{Volcanic Lakes}

\section{Acid Peak-Activity Lakes in a State of Unrest}

Volcanic lakes are the intersection of the crater surface and the underlying aquifer (Fig. 1g, h). Hence, they become "windows" into the depths of magmatic-hydrothermal systems. While fumaroles directly lose their signal from depth to the atmosphere as a "snapshot" (but see Section "When the Gas Hits the Water"), volcanic lakes preserve a past gas marker for a certain period. The time we can track back by studying the water chemistry depends on the duration the water resides in the lake (i.e. residence time). The residence time (RT) is estimated by dividing the lake volume $\left(\mathrm{V}\right.$ in $\left.\mathrm{m}^{3}\right)$ by the input or output rate ( $\mathrm{Q}$ in $\mathrm{m}^{3} / \mathrm{s}$ ) of fluids, assuming steady-state conditions (Varekamp 2003; Rouwet et al. 2014b):

$$
\mathrm{RT}=\mathrm{V} / \mathrm{Q}
$$

Small lakes with high rates of fluid flushing offer a better time-resolution than large lakes with slow rates of fluid in- and output. The monitoring frequency (e.g. lake water sampling) should be tuned to this residence time; a higher monitoring frequency will oversample the lake chemistry, while a lower monitoring frequency will lead to the loss of information the lake potentially provides (Rouwet et al. 2014b).

Volcanic lakes are excellent gas scrubbers. Nevertheless, recent studies quantify the gas release from the lake surface of the most acidic lakes (e.g. Aso, Copahue, Poás, Kawah Ijen; Shinohara et al. 2015; Tamburello et al. 2015; Capaccioni et al. 2016; de Moor et al. 2016; Gunawan et al. 2016). Under the most extreme $\mathrm{pH}$ conditions $(<0) \mathrm{HF}, \mathrm{HCl}$ and even $\mathrm{SO}_{2}$ can degas freely from the lake. This means that acidic lakes are more sensitive than thought before, as acid gas flashes through the water body with only minor scrubbing. Monitoring frequency can thus increase and, hence, spectroscopic or electrochemical sensor tools become extremely useful (DOAS to measure $\mathrm{SO}_{2}$ fluxes from volcanic plumes, Multi-GAS to measure ratios between gas species, e.g. $\mathrm{CO}_{2} / \mathrm{SO}_{2}$ ).

Considering acidic lakes as "open-air" fumaroles (and fumaroles as "buried" acidic lakes) has changed the monitoring time frame, which might lead to better chances to forecast phreatic eruptions (Rouwet et al. 2014a, b; Rouwet and Morrissey 2015).

\section{Volcanic Lake Response to External Triggers in the Absence of Magmatic Unrest}

The Boiling Lake, in Dominica of the Lesser Antilles (a VUELCO target volcano), is a high-temperature volcanic crater lake, that is believed to be formed as a result of phreatic or phreatomagmatic activity (Lindsay et al. 2005). It is approximately $50 \mathrm{~m} \times 60 \mathrm{~m}$ in size and ca. 12-15 m deep, with an estimated volume of $\sim 1.2 \times 10^{4} \mathrm{~m}^{3}$ when filled (Fournier et al. 2009). Over the last 150 years, temperatures taken at the edge of the lake have generally ranged between 80 and $90{ }^{\circ} \mathrm{C}$, and the $\mathrm{pH}$ from 4 to 6 (Joseph et al. 2011), however, the lake experiences periods of instability where water level, temperature and state of hydrothermal activity fluctuate suddenly. The long term stability of the Boiling Lake is attributed to the hypothesis that the lake is suspended above the water table by the buoyancy of rising steam bubbles from the underlying hydrothermal system (Fournier et al. 2009). Perturbations of this interaction as a result of landslides into the lake or regional seismicity is attributed to the cause of the sudden periods of instability (i.e. lake drainage and refill cycles), rather than changes in underlying magmatic activity. This is mainly because no coincident anomalous hydrothermal activity was observed in the Valley of Desolation geothermal area, which is located nearby the Boiling Lake.

The most recent episode of instability occurred during December 2004 to April 2005 (Fig. 6), when the lake water level dropped by $\sim 8-10 \mathrm{~m}$, and the temperature at the water's edge decreased to $<30{ }^{\circ} \mathrm{C}$. Water acidity went from the usual acidic $\mathrm{pH}$ of $4-6$ to neutral, while 
Fig. 6 The refill of an empty Boiling Lake during a period of unusual activity where water levels and geothermal activity were rapidly fluctuating. a An empty Boiling Lake on 7 April 2005. b A full Boiling Lake on 13 April 2005. Pictures by Arlington James, Forestry Officer, Forestry and Wildlife Division, Dominica (used with permission)
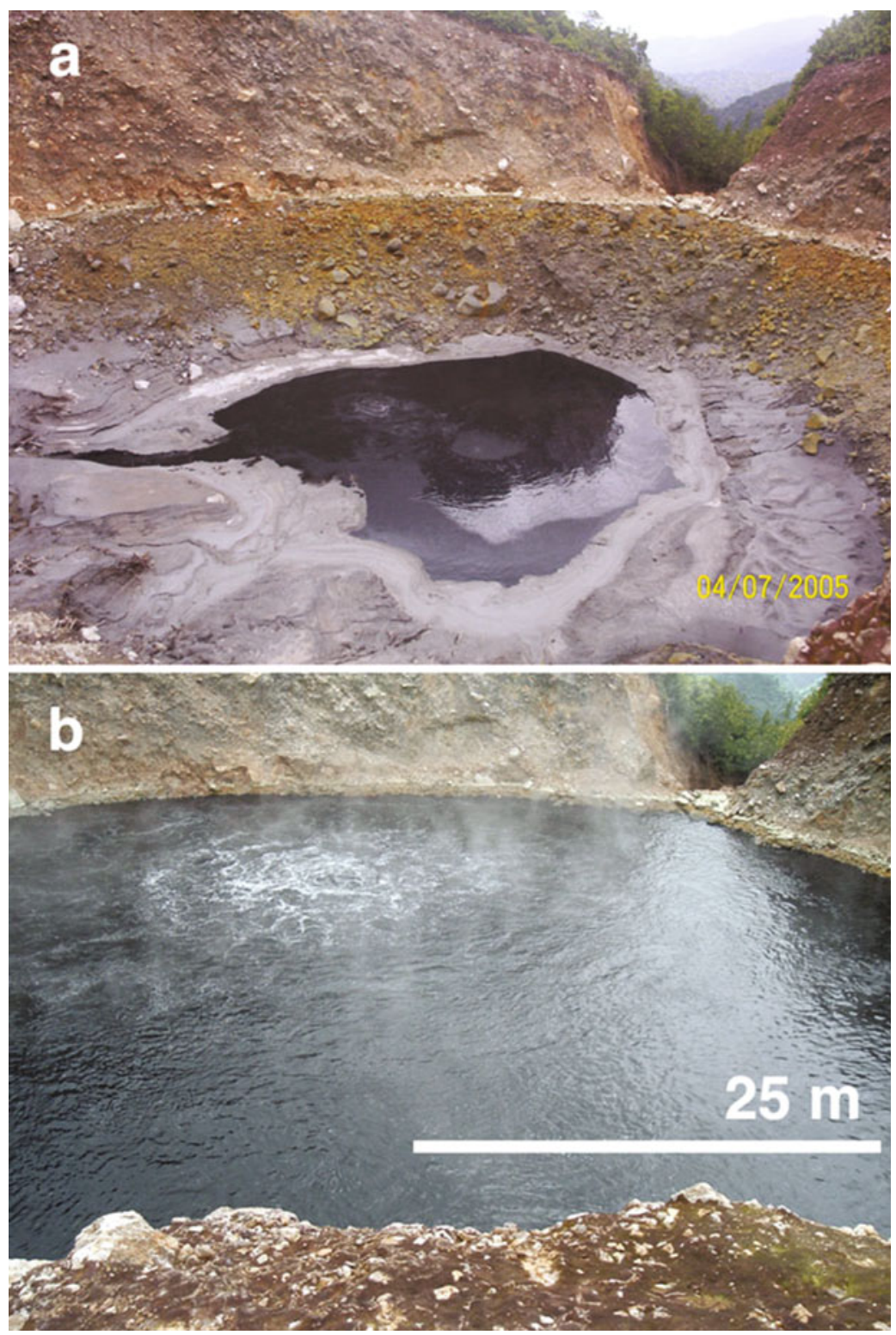

$\mathrm{Cl}$ concentration dropped from the typical 20006000 to $29-50 \mathrm{mg} / \mathrm{L}$, and $\mathrm{SO}_{4}$ concentration dropped from $1500-4000$ to $100-270 \mathrm{mg} / \mathrm{L}$, indicating a drastic decrease of hydrothermal fluid input into the lake (Joseph et al. 2011). Additionally, total dissolved solid content decreased from 13,400 to $4500 \mathrm{mg} / \mathrm{L}$, suggesting strong dilution by fresh water. Measurements of temperature, $\mathrm{pH}$ and chemical composition taken in August 2006 indicate that the lake had returned to its normal steady-state of activity (Joseph et al. 2011). This episode is reported to have been triggered as a result of the extensional strain induced by a regional $\mathrm{Mw} 6.3$ earthquake that occurred on November 21, 2004 offshore Les Saintes (Guadeloupe) (Feuillet et al. 2011), which may have contributed to diminished water inflow.

It should be noted, however, that a phreatic explosion and gas release occurred at an "empty" 
Table 2 Geochemical signals and what they indicate with respect to volcanic unrest

\begin{tabular}{|c|c|c|}
\hline Type of unrest & Geochemical signal & Indication \\
\hline \multirow[t]{4}{*}{ Unrest } & $\mathrm{CO}_{2}$ flux above background & Changes in deep degassing dynamics \\
\hline & Increase in $\mathrm{T}$ of hot springs and/or fumaroles & Increased heat input \\
\hline & Changes in $\mathrm{H}_{2} \mathrm{O} / \mathrm{CO}_{2}$ ratios in fumaroles & Changes in water/gas ratio \\
\hline & Appearance of new fumaroles and/or hot springs & Aerial extension of activity \\
\hline \multirow[t]{5}{*}{ Magmatic unrest } & Appearance of acidic gases $\left(\mathrm{SO}_{2}, \mathrm{HCl}, \mathrm{HF}\right)$ & $\begin{array}{l}\text { Changes in mid- to shallow magma } \\
\text { dynamics }\end{array}$ \\
\hline & T fumarole $>119{ }^{\circ} \mathrm{C}$ & Remobilisation of sulphur \\
\hline & $\mathrm{SO}_{2}$ flux $>\mathrm{X} \mathrm{t} / \mathrm{d}$ & $\begin{array}{l}\mathrm{SO}_{2} \text { flux above background, } \\
\text { volcano-dependent }\end{array}$ \\
\hline & Increase in $\mathrm{CO}_{2} / \mathrm{SO}_{2}$ ratio & Arrival of an undegassed magma at depth \\
\hline & Extreme increase in $\mathrm{T}$ fumaroles $\left(>300^{\circ} \mathrm{C}\right)$ & Towards magmatic $\mathrm{T}$ \\
\hline \multirow{3}{*}{$\begin{array}{l}\text { Magmatic } \\
\text { eruption }\end{array}$} & Decreasing $\mathrm{CO}_{2} / \mathrm{SO}_{2}$ ratios after increase & More superficial magma degassing \\
\hline & $\begin{array}{l}\text { Increase in } \mathrm{Cl}, \mathrm{Br}, \mathrm{F} \text { concentrations in hot } \\
\text { springs/pools }\end{array}$ & Input of highly soluble acidic gases \\
\hline & $\begin{array}{l}\text { Decrease in } \mathrm{H}_{2} \mathrm{O} / \mathrm{CO}_{2} \text { and/or } \mathrm{H}_{2} \mathrm{~S} / \mathrm{SO}_{2} \text { and/or } \\
\mathrm{SO}_{2} / \mathrm{HCl} \text { ratios }\end{array}$ & More gas with a more magmatic signature \\
\hline \multirow{7}{*}{$\begin{array}{l}\text { Hydrothermal } \\
\text { unrest }\end{array}$} & New fumaroles & Aerial extension of activity \\
\hline & Anomalous glacier defrosting & Sudden removal of water mass... lahars \\
\hline & Water to vapour transition & Pushing vapour front from below \\
\hline & Changes in hydrothermal features & Variations or aerial extension of activity \\
\hline & Increase in $\mathrm{B}$ and/or $\mathrm{NH}_{4}$ in waters & Input of vapour \\
\hline & Increase in $\mathrm{CH}_{4} / \mathrm{CO}_{2}$ in fumaroles & $\begin{array}{l}\text { A more hydrothermal signature in } \\
\text { fumaroles }\end{array}$ \\
\hline & Variations in phreatic level in aquifers & Pushing vapour front from below \\
\hline \multirow{4}{*}{$\begin{array}{l}\text { Hydrothermal } \\
\text { eruption }\end{array}$} & $120^{\circ} \mathrm{C}<\mathrm{T}$ fumarole $<200^{\circ} \mathrm{C}$ & Self-sealing by a change in $S$ viscosity \\
\hline & Extension of alteration areas or fumarolic fields & Aerial extension of activity \\
\hline & Appearance of muddy pools & Clearing bugs and vents, unplugging \\
\hline & Boiling/bubbling of pools that previously didn't & $\begin{array}{l}\text { Rising vapour front and/or extra heating } \\
\text { and degassing }\end{array}$ \\
\hline
\end{tabular}

Boiling Lake on 10 December 1901 that resulted in the deaths of two individuals (Elliot 1938; Bell 1946). This suggests that hazards related to volcanic lakes such as the Boiling Lake, may occur without magmatic input.

\section{Take-Home Ideas: Implications for Geochemical Monitoring}

Over the past five-six decades, gas geochemistry at magmatic-hydrothermal systems has mainly focussed on chemical equilibria and kinetics in the subsurface environment. Over the last 1015 years more attention has been paid to remote sensing of volcanic gas plumes (DOAS, Multi-GAS) with the obvious advantage of increased safety and frequency of data gathering. Nevertheless, the relationship between the fumarole and plume has yet to be better constrained. The best proxy of a magmatic gas remains a direct sample of a high-temperature fumarole, although such target fumaroles are often inaccessible, especially during eruptive phases. Compromises between data fidelity and safety of the operators, and the frequency of data 
gathering should be framed in terms of what we want and maximally can unravel. The advantage of fluid geochemistry in volcano monitoring arrises from the fact that volatiles are mobile and thus reach the surface often before physical changes manifest. Timely recognition of unrest and especially hydrothermal unrest is often possible. Table 2 summarizes geochemical signals and how they relate to the various states of volcanic unrest, useful for monitoring based on deterministic research and probabilistic modeling.

Future research should focus on better constraining degassing dynamics at the surface-atmosphere boundary. Recent studies have demonstrated that extremely acidic aquifers can "slow down" the signal released from gas-dominated magmatic-hydrothermal systems (fumaroles), but "speed up" the signal released from water-dominated systems (e.g. acidic crater lakes). These findings have strong implications for the time frame of magma degassing, and hence for the monitoring frequency.

\section{References}

Aiuppa A, Federico C, Paonita G, Valenza M (2002) S, Cl and $\mathrm{F}$ degassing as an indicator of volcanic dynamics: the 2001 eruption of Mount Etna. Geophys Res Lett 29(11):1559. doi:10.1029/2002GL015032

Aiuppa A, Federico C, Giudice G, Giuffrida G, Guida R, Gurrieri S, Liuzzo M, Moretti R, Papale P (2009) The 2007 eruption of Stromboli volcano: insights from real-time measurements of the volcanic gas plume $\mathrm{CO}_{2} / \mathrm{SO}_{2}$ ratio. J Volcanol Geoth Res 182(221):230. doi:10.1016/j.jvolgeores.2008.09.013

Baldoni E, Rouwet D, Mora-Amador R, Ramírez C, González-Ilama G, Lucchi F, Capaccioni B, Tranne CA, Pecoraino G (submitted) Hydrogeochemical model of the Irazú-Turrialba volcanic complex (Costa Rica) and implications for hazard assessment and volcanic surveillance. In: Caudron C, Capaccioni B, Ohba T (eds) GSL special volume geochemistry and geophysics of volcanic lakes

Bell H (1946) Glimpses of a governor's life-Dominica. Samson Low, London

Campion R, Martínez-Cruz M, Lecocq T, Caudron C, Pacheco J, Pianrdi G, Hermans C, Carn S, Bernard A (2012) Space- and ground-based measurements of sulphur dioxide emissions from Turrialba Volcano (Costa Rica). Bull Volcanol. doi:10.1007/s00445-0120631-z
Capaccioni B, Rouwet D, Tassi F (2016) HCl degassing from extremely acidic crater lakes: empirical results from experimental determinations and implications for geochemical monitoring. In: Caudron C, Capaccioni B, Ohba T (eds) GSL special publications 437 geochemistry and geophysics of volcanic lakes. doi:10.1144/ SP437.12

Capasso G, Favara R, Inguaggiato S (1997) Chemical features and isotopic composition of gaseous manifestations on Vulcano Island, Aeolian Islands, Italy: an interpretative model of fluid circulation. Geochim Cosmochim Acta 61(16):3425-3440

Chiodini G, Liccioli C, Vaselli O, Calabrese S, Tassi F, Caliro S, Caselli A, Agusto M, D'Alessandro W (2014) The Domuyo volcanic system: an enormous geothermal resource in Argentine Patagonia. J Volcanol Geoth Res 272:71-77. doi:10.1016/j.jvolgeores. 2014.02.006

Dinger F, Arellano S, Battaglia J, Bobrowski N, Galle B, Hernández S, Hidalgo $\mathrm{S}$, Hörmann $\mathrm{C}$, Lübcke $\mathrm{P}$, Platt U, Ruíz M, Warnach S, Wagner T (2016) Variations of the $\mathrm{BrO} / \mathrm{SO}_{2}$ molar ratios during the 2015 Cotopaxi eruption. EGU 2016-1001

Collard N, Taran Y, Peiffer L, Campion R, Jacome Paz MP (2014) Solute fluxes and geothermal potential of Tacana volcano-hydrothermal system, Mexico-Guatemala. J Volcanol Geoth Res 288:123131. doi:10.1016/j.jvolgeores.2014.10.012

De la Cruz-Reyna S, Tilling RI (2008) Scientific and public responses to the ongoing volcanic crisis at Popocatépetl Volcano, Mexico: importance of an effective hazards-warning system. J Volcanol Geoth Res 170:121-134

Delmelle P, Bernard A (2015) The remarkable chemistry of sulfur in hyper-acid crater lakes: a scientific tribute to Bokuichiro Takano and Minoru Kusakabe. In: Rouwet D, Christenson B, Tassi F, Vandemeulebrouck J (eds) Book chapter in volcanic lakes, Springer, Heidelberg, pp 239-260. doi:10.1007/9783-642-36833-2_10

Delmelle P, Henley RW, Opfergelt S, Detienne M (2015) Summit acid crater lakes and flank instability in composite volcanoes. In: Rouwet D, Christenson B, Tassi F, Vandemeulebrouck J (eds) Book chapter in volcanic lakes. Springer, Heidelberg, pp 289-306. doi:10.1007/978-3-642-36833-2_12

de Moor JM, Aiuppa A, Pacheco J, Avard G, Kern C, Liuzzo M, Martinez M, Giudice G, Fischer TP (2016) Short-period volcanic gas precursors to phreatic eruptions: insights from Poás Volcano, Costa Rica. Earth Planet Sci Lett 442:218-227. doi:10.1016/j.epsl. 2016.02.056

Elliot EC (1938) Boiling lake- the 1900 story. In: Broken Atoms. Unpublished report presented to the Government of Dominica

Feuillet N, Beauducel F, Jacques E, Tapponnier P, Delouis B, Bazin S, Vallée M, King GCP (2011) The $\mathrm{Mw}=6.3$, November 21, 2004, Les Saintes earthquake (Guadeloupe): Tectonic setting, slip model 
and static stress changes. J Geophys Res 116(B10):125. doi:10.1029/2011JB008310

Fournier N, Withal F, Moreau-Fournier M, Bardou L (2009) The Boiling Lake of Dominica, West Indies: high temperature volcanic crater lake dynamics. J Geophys Res 114:B02203. doi:10.1029/ 2008JB005773

Giggenbach WF (1987) Redox processes governing the chemistry of fumarolic gas discharges from White Island, New Zealand. Appl Geochem 2:143-161

González G, Mora-Amador R, Ramirez C, Rouwet D, Alpizar Y, Picado C, Mora R (2015) Actividad historica y analysis de la amenaza del volcano Turrialba, Costa Rica. Rev Geol Am Centr 52:129149. doi:10.15517/rgac.v0i52.19033

Gunawan H et al (2016) New insights into Kawah Ijen's volcanic system from the wet volcano workshop experiment. In: Caudron $\mathrm{C}$, Capaccioni $\mathrm{B}$, Ohba $\mathrm{T}$ (eds) GSL special volume geochemistry and geophysics of volcanic lakes

Hall M, Mothes P (2008) The rhyolitic-andesitic eruptive history of Cotopaxi volcano, Ecuador. Bull Volcanol 70:675-702. doi:10.1007/s00445-007-0161-2

Ingebritsen SE, Galloway DL, Colvard EM, Sorey ML, Mariner RH (2001) Time variation of hydrothermal discharge at selected sites in the western United States: implications for monitoring. J Volcanol Geoth Res 111:1-23

Joseph EP, Fournier N, Lindsay J, Fischer T (2011) Gas and water geochemistry of geothermal systems in Dominica, Lesser Antilles island arc. J Volcanol Geoth Res 206(1-2):1-14. doi:10.1016/j.volgeores. 2011.06.007

Kusakabe M, Komoda Y, Takano B, Abiko T (2000) Sulfur isotopic effects in the disproportionation reaction of sulfur dioxide in hydrothermal fluids: implications for the $\mathrm{d} 34 \mathrm{~S}$ variations of dissolved bisulphate and elemental sulfur from active crater lakes. J Volcanol Geoth Res 97:287-307

Lindsay J, Robertson R, Shepherd J, Ali S (2005) Volcanic hazard atlas of the Lesser Antilles. In: 279. St. Augustine: Seismic Research Unit, University of the West Indies

Martini F, Tassi F, Vaselli O, Del Potro R, Martínez M, Van der Laat R, Fernandez E (2010) Geophysical, geochemical and geodetical signals of reawakening at Turrialba volcano (Costa Rica) after 150 years of quiescence. J Volcanol Geoth Res 198:416-432. doi:10.1016/j.jvolgeores.2010.09.021

Menyailov IA, Nikitina LP, Shapar VN, Pilipenko VP (1986) Temperature increase and chemical changes of fumarolic gases at Momotombo volcano, Nicaragua, in 1982-1985: are these indicators of a possible eruption? J Geophys Res 187:12199-12214

Mora-Amador R, Ramírez-Umaña C, González G, Rouwet D, Lucchi F, Forni F, Sulpizio R, Baldoni E, Alpízar-Segura Y, Tranne CA (2015) First documentation of the ongoing phreatic-strombolian eruptions of Turrialba volcano (Costa Rica). IUGG General Assembly, Prague 3746
Moussallam Y, Peters N, Ramirez C, Oppenheimer C, Aiuppa A, Giudice G (2014) Characterisation of the magmatic signature in gas emissions from Turrialba Volcano, Costa Rica. Solid Earth 5:1341-1350. doi:10.5194/se-5-1341-2014

Oppenheimer C, Stevenson D (1989) Liquid sulphur lakes at Poás volcano. Nature 342:790-793

Phillipson G, Sobradelo R, Gottsmann J (2013) Global volcanic unrest in the 21st century: an analysis of the first decade. J Volcanol Geoth Res 264:183-196

Rouwet D, Morrissey M (2015) Mechanisms of crater lake eruptions: physical and numerical modeling. In: Rouwet D, Christenson B, Tassi F, Vandemeulebrouck J (eds) Book chapter volcanic lakes. Springer, Heidelberg, pp 73-92. doi:10.1007/978-3-642-368332_3

Rouwet D, Ohba T (2015) Iotope fractionation and $\mathrm{HCl}$ partitioning during evaporative degassing from active crater lakes. In: Rouwet D, Christenson B, Tassi F, Vandemeulebrouck J (eds) Book chapter volcanic lakes. Springer, Heidelberg, pp 179-200. doi:10.1007/ 978-3-642-36833-2_7

Rouwet D, Sandri L, Marzocchi W, Gottsmann J, Selva J, Tonini R, Papale P (2014a) Recognizing and tracking hazards related to non-magmatic unrest: a review. J Appl Volcanol 3:17. doi:10.1186/s13617-014-00173

Rouwet D, Tassi F, Mora-Amador R, Sandri L, Chiarini V (2014b) Past, present and future of volcanic lake monitoring. J Volcanol Geoth Res 272:78-97. doi:10. 1016/j.jvolgeores.2013.12.009

Rouwet D, Mora-Amador R, Ramírez-Umaña C, González G, Inguaggiato S (2016) Dynamic fluid recycling at Laguna Caliente (Poás, Costa Rica) before and during the 2006-ongoing phreatic eruption cycle (2005-2010). In: Caudron C, Capaccioni B, Ohba T (eds) Geochemistry and geophysics of volcanic lakes. Geological Society London Special Publications. doi:10.1144/SP437.11

Shinohara H, Giggenbach WF, Kazahaya K, Hedenquist JW (1993) Geochemistry of volcanic gases and hot springs of Satsuma-Iwojima, Japan: following Matsuo. Geochem J 27:271-285

Shinohara H, Yoshikawa S, Miyabuchi Y (2015) Degassing activity of a volcanic crater lake: volcanic plume measurements at the Yudamari crater lake, Aso volcano, Japan. In: Rouwet D, Christenson B, Tassi F, Vandemeulebrouck J (eds) Book chapter volcanic lakes. Springer, Heidelberg, pp 73-92. doi:10.1007/978-3-642-36833-2_8

Symonds RB, Gerlach TM, Reed MH (2001) Magmatic gas scrubbing: implications for volcano monitoring. J Volcanol Geoth Res 108:303-341

Tamburello G, Agusto M, Caselli A, Tassi F, Vaselli O, Calabrese S, Rouwet D, Capaccioni B, Di Napoli R, Cardellino C, Chiodini G, Bitetto M, Brusca L, Bellomo S, Aiuppa A (2015) Intense magmatic degassing through te lake of Copahue volcano, 2013-2014. J Geophys Res doi:10.1002/ 2015JB012160 
Taran YA, Hedenquist JW, Korzhinsky M, Tkachenko SI, Shmulovich KI (1995) Geochemistry of magmatic gases from Kudryavy volcano, Iturup, Kuril Islands. Geochim Cosmochim Acta 59:1749-1761

Taran YA, Peiffer L (2009) Hydrology, hydrochemistry and geothermal potential of El Chichón volcanohydrothermal system, Mexico. Geothermics 38:370-378

Taran YA, Pokrovsky BG, Dubik YM (1989) Isotopic composition and origin of water from andesitic magmas. Dokl Acad Sci 304:440-443

Open Access This chapter is licensed under the terms of the Creative Commons Attribution 4.0 International License (http://creativecommons.org/licensesby/4.0/ which permits use, sharing, adaptation, distribution and reproduction in any medium or format, as long as you give appropriate credit to the original author(s) and the source, provide a link to the Creative Commons license and indicate if changes were made.
Varekamp JC (2003) Lake contamination models for evolution towards steady state. J Limnol 62(1):67-72

Vaselli O, Tassi F, Duarte E, Fernández E, Poreda RJ, Delgado Huertas A (2009) Evolution of fluid geochemistry at the Turrialba volcano (Costa Rica) from 1998 to 2008. Bull Volcanol. doi:10.1007/s00445009-0332-4
The images or other third party material in this chapter are included in the chapter's Creative Commons license, unless indicated otherwise in a credit line to the material. If material is not included in the chapter's Creative Commons license and your intended use is not permitted by statutory regulation or exceeds the permitted use, you will need to obtain permission directly from the copyright holder.

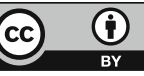

